\title{
Forms of Modern Lawmaking in the System of a Theoretical and Applied Paradigm of Law Knowledge
}

\author{
Bobrovnyk Svitlana, Shevchenko Anatolij, Didych Taras.
}

\begin{abstract}
In article authors established relevance of scientific knowledge of forms of modern lawmaking as special communicative and institutional model of emergence and development of law. High level of relevance of scientific knowledge of forms of modern lawmaking of the system of a theoretical and applied paradigm of law knowledge proved. The expediency of allocation of forms of modern lawmaking proved. Based on generalization of forms of modern lawmaking their characteristic as a law knowledge subject component is specified.

The doctrinal form of lawmaking can be characterize within the following provisions. It is noted that forms of modern lawmaking are the category designating: first, the spatial component, that is characterizes (reflects) external manifestation, a certain model, a stamp of the studied phenomenon; secondly, the substantial component as covers regularities of content of formation of law, includes the system of its elements and features of interaction between them; thirdly, an organizational component which is based on understanding of a form as special means of the organization of content of lawmaking. It is proved that based on this complex understanding of forms of modern lawmaking, it is expedient to continue a research of its theoretical and practical aspects.
\end{abstract}

Keywords : lawmaking, formations of law, lawmaking form, current state of lawmaking, law knowledge.

\section{INTRODUCTION}

Scientific research of theoretical and applied aspects of any legal phenomenon through a prism of a form of its manifestation has important informative value as allows to open and characterize the studied phenomenon as a special phenomenon which properties define its place in the system of other phenomena of legal reality and characterizes its ability to be the apprehended and intelligent legal entities. Therefore lawmaking manifestation forms, especially its expressions in social reality at the present stage of its development, influence of factors of law knowledge, stability and functionality of lawmaking as legal phenomenon is one of its informative theoretical and applied aspects reflecting character and result of manifestation of the formation of law and also distribution of informative ideas of it in the course of scientific or educational activity. The specified features of lawmaking accumulate categories of «a lawmaking form» that reflects

Revised Manuscript Received on November 15, 2019

* Correspondence Author

Bobrovnyk Svitlana, Professor, Faculty of law, Kiev Taras Shevchenko University, Kyiv Ukraine

Shevchenko Anatolij, Professor, Educational and Scientific Institute of Law, National University of the State Fiscal Service of Ukraine, Irpen, Ukraine

Didych Taras, Associate professor, Faculty of law, Kiev Taras Shevchenko University, Kyiv Ukraine and characterizes its internal contents and external manifestation as expression of the nature, essence and process of formation of the law and defines its further knowledge.

The analysis of the last publications on a perspective and allocation of parts of a common problem unresolved earlier. Existence of forms of lawmaking was proved even in works of representatives of historical school of law (K. Savinya, F. Pukht) which indicated that the historical character has formation of law, comes from a combination of various factors of public life, caused by regularities of their historical development and its formalization in the form of specific forms is [1, p. 34]. Forms of lawmaking is external manifestation of difficult process of origin of law, its formation and formalization [2, p. 62].

In scientific aspect and scientifically perspective views of modern scientists in which, despite a rarity of a research of forms of lawmaking, their independence as object of scientific knowledge stated are the most interesting, reflects plurality of aspects of lawmaking and a possibility of its structuration on separate forms. In modern legal literature as we already noted a perspective of forms of lawmaking opened rather incidentally, unlike a research of content of lawmaking. Most of the scientists-jurists investigating a lawmaking perspective in general bypass a question of existence of its forms.

At the same time, the form of lawmaking is one of key aspects of the studied phenomenon, plays importance as regarding the analysis of aspects of external identification of lawmaking, and aspects of its organizational influence on formation of law. First of all, it is necessary to pay attention that there is no uniform unified approach to understanding of forms of lawmaking at all therefore they are defined as a way, ways of emergence (formation) of law [3, p. 23]; an element of process of formation of law which provides the translation of the public relations which actually developed in the rule, instructions which find the expression in the written act [4, p. 19]; a stage of formalization of the legal ideas which formally are fixed as the provisions of positive law [5, p. 295]; a way of recognition legal those norms which arose in a subsoil of primitive society, at the final stage of its development when proto-states began to be formed [6, p. 219]. In addition, G.V. Maltsev adheres to the similar point of view, paying attention that the common law turned out to be consequence of development of the public relations and further coexisted with the public power and vessels, cooperated with them [7, p. 27].L.M. Shestopalova considers lawmaking forms, characterizing them as forming the law in the form of its corresponding forms, which provide its formal expression, and fixing [8, p. 103-105].

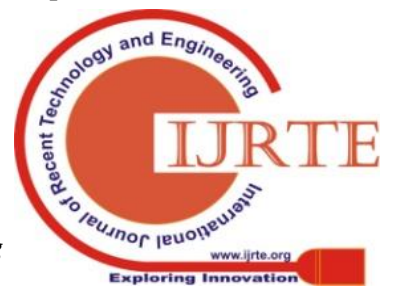


The analysis of the specified views of scientists could be continue, however they have the same character and in general characterize lawmaking in terms of its ability to provide by means of authorized subjects external expression of rules of law in the form of the concrete carrier of standard legal information. In foreign scientific works the problem of forms of formation of law was most thoroughly researched by representatives of legal realism (J. Holmes, J. Frank and K. Llevellin) who considered origins of the law as a form of manifestation of experience of legislators, expressions in it their researches [9, p. 5], forecasting of probable behavior of judges at the solution of affairs on the basis of that situation which is planned to be fixed by the concrete act[10, p. 409]. In the western jurisprudence in the 20th century rather wide range of the works of praxeological character concerning questions of forms of origin (formation) of law in this or that branch of law [11] at the international level was created [12; $13 ; 14 ; 15]$, in particular within the boundaries of specific states [16]; at the level of lawmaking [17], factors influencing them and further determine the specifics of the content of law [18] etc.

Lawmaking forms including modern, reflect its real existence, are shown in the form of the corresponding external manifestations that allow be apprehending and comprehending as at the daily, and doctrinal level. By scientific researches of forms of modern lawmaking it is possible to determine consistent patterns of influence of factors of lawmaking on contents and the nature of precepts of law, their change or cancellation, to analyze its nature and essence as means of formation of the new phenomenon or updating existing, result of its functioning which is formed in the form of the corresponding material carrier of legal information and reflects the nature of its distribution within society. The present stage of development of scientific research of lawmaking demands thorough reconsideration of problems of forms of lawmaking that will allow: to consider and to comprehensively investigate the scientific potential of lawmaking, having provided knowledge of key aspects of the studied phenomenon including features of forms of its detection; to overcome long impact of ideological factors on scientific research of lawmaking including on understanding of forms as the derivative characteristic of lawmaking caused by its contents.

\section{MATERIALS AND METHODS}

2.1. Formulation of the purpose (purposes) of a research. Specified proves the high level of relevance of scientific knowledge of forms of modern lawmaking of the system of a theoretical and applied paradigm of law knowledge and defines the purpose (purposes) of a research: prove expediency of selection of forms of modern lawmaking, carry out their generalization and specify their characteristic as a law knowledge subject component.

2.2. Statement of the main results and their justification. The expediency of allocation of forms of lawmaking first of all is caused by properties of the phenomenon which: first, it is based on various public relation which defines emergence, development and change of law which receives external manifestation; secondly, includes various ways of lawmaking caused by the corresponding process of such formation, are allocated with the authentic content of formation of law and are aimed at achievement of

concrete result.

According to us, a form of lawmaking is a communicative and institutional component of process of formation of law that reflects features of interaction between subjects of society and their influence on origin, formation and external manifestation of rules of law. The form of lawmaking is the generalizing concept defining interrelation between lawmaking factors, origin and development of law and its external manifestation where regularities of such interrelation allow to distinguish a complex of forms of lawmaking that to disclose backbone characteristics of the phenomenon investigated by us. The value of forms of lawmaking is shown that they:

-first, allow to generalize the public relations which define the maintenance of factors of lawmaking, to prove regularities of their influence on formation of law;

-secondly, establish an opportunity to provide fixing of rules of conduct of subjects, to provide them the obligatory, standard, system, formally defined and not personified character;

-thirdly, is means of expression of will of individuals, having provided coordination and balancing of their interests and requirements, the embodiment of will of authorized subjects of creation of law.

\section{RESULTS}

3.1. Forms of modern lawmaking. Forms of modern lawmaking are a concept of system character, which structured on separate elements (forms) which accumulate in themselves the most typical regularities of origin, formation and development of the public relations, interrelations between them, generalizing features of their influence on formation of law and its contents. Therefore the most optimum approach to allocation of forms of modern lawmaking, according to us, is approach according to which in a basis of criterion of their allocation the features of the public relations defining emergence of law, its development, change (communicative and legal criterion) and also the nature of a juridization of law, its registration in the form of specific forms (institutional and legal criterion) have to be put. The combination of the specified criteria of allocation of forms of lawmaking allows:

-to take features of content of lawmaking where interaction of the public relations defines need of creation of the law as a basis;

-to define features of external detection of the lawmaking in the form of specific institutional forms.

3.2. Traditional form of formation of law. Combining communicative and legal and institutional and legal criteria for allocation and the analysis of kinds of forms of modern lawmaking, first of all it is necessary to allocate a traditional form of formation of law. The specified form of formation of law has primary character, as it is directly base on the public relation, objectively forms rules of conduct, which owing to authoritativeness, repeated repetition acquire the obligatory status. The communicative and institutional nature of a traditional form of lawmaking is show that: 
-a traditional form of formation of law has the greatest degree of historical conditionality, accumulates and reflects the nature of culture of the relevant society, embodying them in the content of precepts of law;

-the maintenance of atraditional form of lawmaking is the special circle of the public relations which arise and develop under the influence of various factors of social development, thereby gaining steady, socially recognized character;

- a positive aspect of a traditional form of lawmaking is that in its basis there is a natural basis of emergence of law, and rules of conduct develop gradually, and therefore consider the changes happening in the public relations. It allows to receive to rules of law the high level of public recognition and authoritativeness of their distribution in society;

-the institutionallyof a traditional form of lawmaking is shown that usual norms demand the corresponding recognition and authorization from authorized subjects, provides to norms the corresponding form of expression and legal status.

In spite of the fact that a traditional form of lawmaking has natural, historically and socially caused character, it has no exclusive character and cannot exist and function without other forms of lawmaking, besides, the specified form of lawmakinghas rather conservative character, it is fully not capable to provide timely streamlining of the public relations, to achieve legal result in the short term.

3.3. Features of a case form of lawmaking. The following form of lawmaking it is necessary to call the case form of formation of law based on activities of authorized subjects for consideration of a concrete life situation, decision-making that acquires further the obligatory status and not personified character. The specified form of lawmaking finds the manifestation in the form of the judicial (administrative) document enshrining precepts of law, accepted by authorized judicial or administrative body of law enforcement, has obligatory value at the solution of similar cases in the future. Features of a case form of lawmaking consist in the following:

-formation of rules of law in the form of a precedent is based on special kinds of the public relations having conflict and at the same time typical character which causes expediency of their consideration by an authorized subject and adoption of the relevant decision which will provide approach for these subjects of consequence in law;

-formation of law happens on the basis of consideration and decision-making on a certain life situation, has typical (widespread) character. That is a basis of this form are the typical public relations making the maintenance of a life situation;

-the result of a case form of lawmaking is shown not so much in creation of a precedent how many in its regulating distribution on the public relations, has to provide efficiency and timeliness of the solution of similar vital circumstances;

-in terms of communicative properties of a case form of lawmaking, the specified form has the dynamic nature of development as considers changes in public life which dynamics directly influences formation of law in a case form.

At the same time, the case form of lawmaking allows to consider features and circumstances of consideration of each separate cases.

3.4. Contractual form of lawmaking. Contractual form of lawmaking - the following form that we allocate within the analysis of kinds of forms of lawmaking. Its sense is that established rules of law find the fixing in the form of provisions of the standard legal instrument that is the contractual act of two or more parties, by mutual consent establish new rules of law that are obligatory for persons of law. At the same time, the contractual form of lawmaking has the features to which it is necessary to refer the following:

-the public relations develop by achievement of arrangements between legally equal subjects which could align the interests and reach consent concerning approach of the corresponding consequence in law. As a result of coordination of interests between subjects the contents of rules of law of the general legal character were agreed and further are set formally defined, not personified character in a type of the corresponding standard legal instrument which norms get obligatory;

-the public relations making a basis of a contractual form of lawmaking can have as bilateral, and multilateral character. It is explained by a variety of interests of the parties of a contractual form of lawmaking, on the one hand, and generality and non-personified provisions which are enshrined, on the other hand, that demands accounting of interests of a wide range of subjects;

-the public relations defining a contractual form of lawmaking have both interstate (national) character, and international. Respectively, and rules of law which are formed as realization of a contractual form of lawmaking are an element of either national, or international law;

-the public relations which define a contractual form of lawmaking are the relations of domination or management, or have coordination character. In the first case the imperious or administrative relations cause formation of rules of law and their fixing in the form of the standard legal instrument signed between subjects which are in the submission relations and contents of these rules of law reflects realization of imperious or administrative function by an authorized subject. The coordination nature of the relations making a basis of a contractual form of lawmaking defines the conclusion of the standard legal instrument between legally equal subjects, which enshrine rules of law in those spheres where they carry out joint activity, or for overcoming the conflicts between them.

Despite advantages of a contractual form of lawmaking, nevertheless it cannot be neither only, nor dominating as finally uncertain is a role of the state in formation of law in a contractual form. Besides, the specified form of lawmaking is functionally capable to form the law only in the separate branches (institutes) of law, without providing an integrated system approach to lawmaking, thereby is capable to provide a further effective legal regulation of the public relations. Effective functioning of a contractual form oflawmaking is possible only in case of its combination to other forms of lawmaking.

3.4. The standard and legal form of lawmaking. The standard and legal form of lawmaking provides establishment, change or cancellation of rules of law by formation and detection of objective need of change of legal regulation with unilateral strong-willed creative activities for development, acceptance and enforcement of the normative legal acts enshrining rules of law. Such

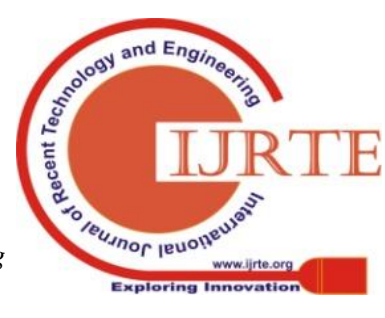


form of lawmaking connected with a number of characteristics that combine features of formation of law as conscious, strong-willed creative activity and property of normative legal acts, which are a form of fixing of the created precepts of law. The following belongs to such characteristics:

-it is based on the public relation which defines objective need of change of legal regulation, it is possible to reach only by unilateral law-making will of the subject given powers of authority;

-is defined by thorough work of authorized subjects on detection of objective need of change of legal regulation which is formed on the basis of the existing public relations which influence further contents of new rules of law, change or cancellation existing and also define character and content of further legal regulation;

-it is connected with development, acceptance and enforcement of the special legal document - the normative legal act which is the legal document, it is formed by authorized subjects in the course of formation of law, contains precepts of law and it is allocated with the corresponding validity;

-is implemented in accurately certain order, that is has procedural character, providing effectiveness of formation of law, quality of precepts of law and efficiency of their realization. The procedurally of the studied form of lawmaking is caused by high degree of dependence on subjects of formation of law which are accurately defined, allocated with legislatively set status which provide gradualness of lawmaking, its expression in the form of the corresponding form of law and further realization.

\section{IV.DISCUSSION}

Separately it should be note about existence of a doctrinal form of lawmaking, based on the scientific activity providing knowledge and further action of law by justification of provisions that gain standard, obligatory value. The doctrinal form of lawmaking can be characterize within the following provisions:

- at the heart of a doctrinal form of lawmaking there are public relations. The doctrinal form of lawmaking originates from the public relations which are regulated by means of precepts of law, thereby reflect a condition of legal regulation of the public relations, its advantages and shortcomings which define further formations of law in the form of the legal doctrine;

- the doctrinal form of lawmaking provides establishment, change or cancellation of legal regulation of the public relations, providing the obligatory and standard status of provisions of the legal doctrine;

- this form of lawmaking exists and functions in the form of accurately certain evidence-based system of provisions, the ideas, the principles and concepts which get further obligatory character;

- it has the formal expression in the form of a certain documentary carrier, fixing the legal ideas, the principles, provisions, concepts, provides their accumulations, storages, distribution on the public relations.

\section{V.CONCLUSION}

At the same time the doctrinal form of lawmaking takes the independent place in the system of forms of lawmaking as it, on the one hand, based on various public relation which defines emergence, development and change of law, receives external manifestation, and with another - represents an independent way of lawmaking which is caused by the authentic nature of origin of rules of law, the corresponding process and content of such formation, is characterized by the purpose of improvement of legal regulation and creation of rules of law. The specified form of lawmaking accumulates in itself the most typical regularities of origin, formation and development of the public relations, interrelations between them, generalizing features of their determining influence on creation of law and its contents. However the doctrinal form of lawmaking has no exclusive character, and is an independent element of forms of lawmaking, is explained by its rather official status, which subject is not only researches of the state and legal phenomena, but also rules of law enshrined in a form of the legal doctrine, having abstract character, and which are not accurately formalized.

\section{REFERENCES}

1. Savy`n`y`F. K. Obyazatel`stvennoe pravo / Perevod s nem. V. Fuksa y N. Mandro. - S.-Pb. : Yury`dy`chesky`j centr «Press», 2004. - 576 s.

2. Puxta G. F. Ency`klopedy`ya prava / G. F. Puxta - M. : Kny`ga po Trebovany`yu, 2011. - 101 s.

3. Grevczov Yu. Y`. Formy pravoobrazovany`ya y` yury`dy`cheskaya texny`ka // Yury`dy`cheskaya texny`ka. - 2012. - № 6. - S. 22-27.

4. Man`ko D. G. Texnologiyi formalizacziyi prava // Naukovy`j visny`k Mizhnarodnogo gumanitarnogo un-tu. Seriya: Yury`sprudenciya. 2013. - № 5. - S. 18-21.

5. Pry`dvorov N. A., Trofy`mov V. V. Pravoobrazovany`e y` pravoobrazuyushhy`e faktory v prave. - M. : NORMA-Y NFRA-M, 2012. - 399 s.

6. Kashany`na T. V. Proy`sxozhdeny`e gosudarstva y` prava : uchebnoe posoby`e. - M. : Vysshaya shkola, 1999. - $325 \mathrm{~s}$.

7. Mal`cev G. V. Pyat` lekcy`j o proy`sxozhdeny`y`y` ranny`x formax prava. - M. : Y`zd-vo RAGS, 2000. - 364 s.

8. Teoriya derzhavy`i prava : navch. posib. / Uporyad. L. M. Shestopalova. - K. : Precedent, 2004. - 224 s.

9. The Common Law / ed. Mark DeWolfe Howe. - Boston : Little, Brown, 1963. - 337 p.

10. Cappelletti M. The „Mighty Problem” in Judicial Review and the Contribution of Comparative Analysis / M. Cappelletti // Legal Issues of Eur. Integration. - 1979. - № 1. - P. 409-418.

11. Holmes O. The Common Law / O. Holmes. — Boston, 1938. - 270 p

12. Elberling B. The Ultra Vires Character of Legislative Action by the Security Council / B. Elberling // International Organizations Law Review. - 2005. - Vol. 2, Issue 2. - P. 337-360.

13. Singh N. N. The Legislative Process in International Law: A General Comment / N. N. Singh // Bond Law Review. - 1990. - Vol. 2, Issue 2. - P. 172-181.

14. Szasz P. C. The Security Council Starts Legislating / P. C. Szasz // American Journal ofInternational Law. - 2002. - № 4 . - P. 901-905.

15. Talmon S. The Security Council as World Legislature / S. Talmon // American Journal of International Law. - 2005. - Vol. 99. - P. 175-193.

16. Mehmet Kanbur, Tomasz Bernat Europeanization in Turkey and accession process to the European Union // Journal of International Studies, 2013. - Vol. 6. - No 2. - P. 79-93.

17. Waldron J. The Blackwell Guide to the Philosophy of Law and Legal Theory / J. Waldron. - Blackwell : Blackwell Publishing, 2005. - P. 236-247.

18. Tran Van H., Tran Huu, A., D Ushakov Liberal reforms \& economic growth: Current issues and interrelations // Journal of International Studies. - 2017. - No 10(4). - P. 109-118.

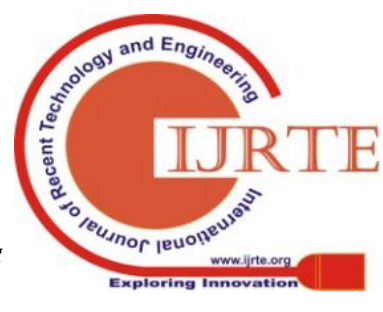




\section{AUTHORS PROFILE}

Bobrovnyk Svitlana, Professor, Faculty of law, Kiev Taras Shevchenko University, Kyiv Ukraine

Shevchenko Anatolij, Professor, Educational and Scientific Institute of Law, National University of the State Fiscal Service of Ukraine, Irpen, Ukraine

Didych Taras, Associate professor, Faculty of law, Kiev Taras Shevchenko University, Kyiv Ukraine

Corresponding author: Email: tarasdid@ukr.net, Tel $+38096-4592956$ 